\title{
REPUBLIC OF CHINA ARMED FORCES AND THEIR MODERNIZATION IN THE YEARS 2017-2020 IN THE BACKGROUND OF THE GEOPOLITICAL CRISIS IN RELATIONS WITH THE PEOPLE'S REPUBLIC OF CHINA (PRC)
}

\begin{abstract}
This paper examines the development of the military potential of Taiwan (ROC) in 2017-2020 against the background of threats resulting from the aspirations of the People's Republic of China. Taiwan is one of the fastest developing countries in the world. This paper presents the latest trends in terms of the scale and scope of modernization of the Taiwanese armed forces, with particular regard to land forces in 2017-2020, and the factors that had a direct impact on the process, such as its geopolitical location and power, and the ever-increasing threat from China. Both of these countries strive to maximize their power and preserve their interests in joint relations. Realism as a doctrine of international relations is well known and implemented in the PRC, and factors such as nationalism only strengthen it. Taiwan is still considered part of its former "homeland," and Taipei's proclamation of independence could lead to war, even if the Chinese economy were to suffer. On the other hand, Taipei's raison d'être is to ensure its own security through the development of its military and economic potential and faith in external help. Mutual fears between Taipei and Beijing and other countries in the region are exacerbated by the so-called security dilemma, which means that any actions aimed at ensuring greater military potential by China will be poorly received in Tokyo, Seoul, Hanoi, Taipei, and especially in Washington, and will cause even greater armament on their part, which may lead to war.
\end{abstract}

Keywords: Taiwan, military, Republic of China Armed Forces, Taiwan Army's equipment modernization, geopolitics, military security.

\section{INTRODUCTION}

Taiwan (Republic of China - ROC) is located in East Asia between the Taiwan Strait, the South China Sea, the East China Sea and the Philippine Sea. It includes the island of Taiwan itself (with an area of 35.8 thousand $\mathrm{km}^{2}$ ) and 21 offshore islands and the Pescadora archipelago. The Cairo Conference in 1943 decided on the return of Taiwan to Chinese rule after the liberation from Japanese rule which took place in 1945. In 1949 the authorities of the Republic of China and the remnants of Chiang Kai-shek's army were evacuated to the

\footnotetext{
${ }^{1}$ Krzysztof Surowiec, PhD, Department of Humanities and Social Sciences, Faculty of Management, Ignacy Łukasiewicz Rzeszów University of Technology, ul. Podkarpacka 1, 35-082 Rzeszów; e-mail: ks@prz.edu.pl. ORCID: 0000-0002-6298-2260.
} 
island, pushed out of mainland China by the communists, and with them about 2 million refugees. As of January 1, 2002, the Republic of China belongs to the WTO under the name of the Separate Customs Territory of Taiwan, Penghu, Kinmen and Matsu. In March 2005, the People's Republic of China (PRC) threatened Taiwan with a direct military attack if it declared formal independence and adopted an anti-secession law as the legal basis for an attack on the island. According to Ye Zicheng, the PRC will only achieve the status of a real superpower if Taiwan joins (Ye Zicheng, 2011). Taiwan is formally a province of China, but in fact it remains independent of the PRC government. In January 2020, the elections in Taiwan were won for the second time in a row by the Democratic Progressive Party (DPP), and President Caj Ing-wen officially rejected proposals to unite with China, offering in return a constructive, peace-based dialogue. Currently, Taiwan maintains official diplomatic relations with only a dozen of the 193 countries that belong to the United Nations.

The ROC of China has a special political and military relationship with the United States. The US became the guarantor of Taiwan's independence, responding to any flare-up of the situation in the Taiwan Strait. In December 1954, the Mutual Defense Treaty was concluded between the USA and Taiwan. In January 1955, the US Congress adopted The Formosa Resolution under which President Dwight Eisenhower was granted the right to defend Taiwan by Congress (Bush, 2015). As a result of these agreements several thousand American soldiers were stationed in Taiwan during the Cold War. In March 1979, the US Congress passed the Taiwan Relations Act under which the US continues to sell arms to Taiwan. In view of the increased intensity of rivalry between the US and the PRC (Góralczyk, 2019), Washington's relations with Taipei have gained new significance in recent years. Successive US presidents, from George W. Bush Jr., through Barack Obama and Donald Trump, expanded diplomatic and economic relations, also providing modern weapons. Maintaining strong relations with Taiwan is also a prime concern of the US, in line with its pursuit of further peace and stability in Asia and the maintenance of its influence in the region. The last American document strengthening relations with Taiwan was the "TAIPEI" Act signed on March 26, 2020 by President Trump. Its purpose was to expand the US relationship with Taiwan and to encourage other nations and international organizations to strengthen official and unofficial ties with the island.

According to the Global Firepower analyses, which were presented in 2020, Taiwan was 26th in the world in terms of the military strength index (Ching-Tse, 2020). Despite such a high position, Taiwan's ranking dropped four positions compared to the previous year. The study took into account the potential of 136 countries. Global Firepower took several individual factors into account, including each country's ability to wage war by land, sea and air, giving Taiwan a "PowerIndex" score of 0.4008 (for an ideal score of 0.0000). The United States once again took first place, followed by Russia, China, India and Japan.

\section{Purpose of the paper and research methodology}

The purpose of the paper was to present the latest trends in terms of the scale and scope of the modernization of the Taiwanese armed forces with particular regard to land forces in 2017-2020, and the factors that had a direct impact on the described process in the current conditions, resulting from the geopolitical location and power, and the ever-increasing threat from the People's Republic of China. The research problem is summarised in the question of how significantly ROC's military potential has increased in recent years to such an extent that it is possible to maintain political independence from the People's Republic 
of China, which is becoming a hegemon in this region and is fighting with the United States of America for the position of a superpower. The subject of the research was the Taiwan armed forces and their modernization in 2017-2020. In the paper the following methods of science on security have been applied: qualitative (the facts are obtained through deductions and induction of the studied subject and extended exegesis of the subject literature); quantitative (the facts cited can be presented synthetically by means of numbers); empirical (obtaining facts through own experience) and the historical method (leading to the establishment of a historical fact).

\section{DEMOGRAPHIC POTENTIAL AND ECONOMY POWER AND ITS IMPACT ON MILITARY EXPENDITURE}

In 1905, the population of Taiwan was approximately 3 million; by 1940 the population rose to 5.87 million, and by the end of World War II in 1946 it was 6.09 million (Mitchell, 2003). The years after the Second World War were a period of accelerated population growth, whose peak, according to experts' calculations, would fall in the first years of the third decade of the 21 st century. This is confirmed by calculations according to which the population of Taiwan is aging very quickly, which also affects the potential of the country's armed forces. In 2010, population growth in Taiwan was less than $0.2 \%$ and the fertility rate was only 0.9 . It was the lowest rate ever recorded in the country. Taiwan's population is projected to peak at around 23.7 million in 2024 and then decline (The Republic of China Yearbook, 2014). Between 1956 and 1982, Taiwan's population doubled from 9 million to over 18 million. In 2017, the ROC population of the Republic of China was 23.508.428 million (The Military Balance, 2018), in 2018 23.545.963 million (The Military Balance, 2019), in 2019 23.577.456 million (The Military Balance, 2020), and now the estimated population of Taiwan is 23.816.775 million (Taiwan Demographics, Worldometer).

Taking into consideration economy, Taiwan belongs to the so-called "Asian tigers", i.e. countries rapidly developing their economy based on the free market and the development of modern technologies, especially in electronics. With the economic miracle, Taiwan's defense spending also increased in the face of the constant threat from the PRC. In 2017, Taiwan's GDP was \$ 571 billion in current prices, in 2018, \$ 603 billion, in 2019, \$ 586 billion (The Military Balance, 2018, 2019, 2020). At the end of 2020, economists estimate that Taiwan's GDP, despite the Covid-19 epidemic, will be close to the values of $2019^{2}$.

Taipei's military expenditures in the analyzed period classified Taipei in the world's 30, at a similar level as Poland, Egypt, Pakistan and Singapore. In 2017, Taiwan's defense budget was estimated at USD 10.4 billion, in 2018 at USD 11 billion, in 2019 at USD 10.9 billion (The Military Balance, 2018, 2019, 2020), and in 2020 the President of Taiwan proposed a defense budget of over $\$ 13$ billion. In 2019, overall South and East Asia spending increased by $3.4 \%$ to 2018 . special funds for the modernization of the armed forces, most of which will be allocated to the import of weapons from the US. In 2021, this increase would even exceed $10 \%$ to USD 15.42 billion (Bartkiewicz, 2020). The defense budget of the PRC in 2020 is expected to amount to approximately USD 178 billion, and in 2019 it was at the level of USD 261 billion (Szopa, 2020). According to the Globalfirepower military portal, Taiwan's military expenditure in 2020 will amount to approximately USD

\footnotetext{
2 According to sources from Tradingeeconomics and Eurostat.in the second quarter of 2020, Taiwan's GDP fell by only $0.58 \%$ due to the Covid- 19 pandemic.
} 
10.75 billion, which will allow the country to be 27 th out of 138 countries surveyed in terms of defense spending from the state budget (Globalfirepower, 2020).

The currently developing quantitative methods in research on international relations on the basis of selected models also show a specific place of a given country in the international balance of power in terms of its economic (general), military and geopolitical power. The Polish model presenting these three types of power is that of prof. Sulka. According to this model and power measurements, a new bipolar system was developed in 2017 in terms of economic potential, but based on military power, the world remained unipolar. On the basis of geopolitical power, a "weak" bipolar system (with a large US advantage) emerged. China has become a world power according to the power-metric measurements. The methodology of Sułek's model (Sułek, 2013) and the division of powers into three types require appropriate units of measurement. The mire is usually taken as the basic unit. The studied power of states is a fraction of this size (if we assume that our unit will be millimire $(\mathrm{mm})$, i.e. a thousandth of a world power - it is equal to 1000). The power of states is inherently relative, so we measure it in relation to the power of the world as a fixed point of reference.

Based on the Sułek's model and the calculations made according to it for 2017, Taiwan and China rank in the ranking of world powers as follows. According to the measurements of the economic (general) power, in 2017 China took the first position in the world, ahead of the USA with $152.113 \mathrm{~mm}$, while Taiwan took the $33 \mathrm{rd}$ position with the power of $4.691 \mathrm{~mm}$. Taking into account the military power, China took the second position with $100.224 \mathrm{~mm}$, more than twice less than the USA, while Taiwan was the 26th with the power of $5.888 \mathrm{~mm}$. The distribution of geopolitical power in the world according to Sułek's model shows that China came in second with a power of $117,520 \mathrm{~mm}$. Taiwan ranked 28 th in this hierarchy with a geopolitical power of $5.489 \mathrm{mM}$ out of 1000 - the power of the whole world (Sułek, Białoskurski, Kiczma, 2019).

According to the latest power-metric ranking for 2018 (Sułek, Kiczma, 2020), taking into account the economic power of countries calculated on the basis of Professor Sułek's model, China was in the first place in the world, gaining $156.804 \mathrm{~mm}$ (world 1000), slightly increasing the advantage over the USA. Taiwan moved up one position in this ranking (32), gaining $4.561 \mathrm{~mm}$. China's military power in 2018 was $103.334 \mathrm{~mm}$, which gave it the second place in the ranking. On the other hand, Taiwan fell one position (27) with a power of $5.859 \mathrm{~mm}$. In the classification of geopolitical powers, China came second $(121,157)$, and Taiwan moved up one position compared to 2017 (27th place) with a power of 5.426 (Sułek, Kiczma, 2020).

\footnotetext{
3 The Swedish SIPRI institute (Stockholm International Peace Research Institute) reported that global spending on weapons in 2019 increased quite significantly. Spending on armaments amounted to the equivalent of USD 1.917 trillion, which meant an increase by $3.6 \%$ compared to the previous year. There were included: the USA (USD 732 billion, increase by 5.3\%), China (USD 261 billion increase by $5.1 \%$ ) and India (USD 71.1 billion increase by $6.8 \%$ ). Russia came fourth (USD 65.1 billion, up 4.5\%) and Saudi Arabia fifth (USD 61.9 billion, down from the USD \$ 67.6 billion). It was followed by France (USD 50.1 billion), Germany (USD 49.3 billion), Great Britain (USD 48.7 billion), Japan (USD 47.6 billion), South Korea (USD 43.9 billion). SIPRI authors say 2019 was the peak year for military spending, with COVID-19 on the downward trend from 2020. An epidemic may shift funds to fight it, and the widespread decline in GDP also forces a reduction in military spending. On the other hand, the epidemic may cause international tensions, which will stimulate further spending. See SIPRI Military Expenditure Database, https://sipri.org/ databases/milex $(2020,09,27)$.
} 


\section{THE LAND FORCES OF THE REPUBLIC OF CHINA AND THEIR MODERNIZATION IN 2017-2020}

Taiwan, despite the fact that it is a small country, both in terms of territory and population, has quite significant armed forces compared to most other countries in the world's top thirty armies, In 2017, Taiwan had 215.000 active soldiers, including 130,000 in the army, 40.000 in the fleet, 40.000 in the air force, and 11.445 in the paramilitary forces. The strategic reserves amounted to 1.657 .000 soldiers in that year (The Military Balance, 2018). A year later, according to the Military Balance data, the number of the Taiwan armed forces decreased, which was influenced by the professionalization of the army and the internal policy. A decline in the combat readiness of the Taiwanese army was the result of these reforms. According to Maciej Szopa, in 2018 only $81 \%$ of uniformed jobs could actually be filled (Szopa, 2020). The condition of the Taiwanese army in 2018 was 163.000 , of which 88.000 served land, 40.000 in the fleet, 35.000 in aviation, and over 11.000 paramilitary troops. (The Military Balance, 2019). The size of the reserves remained at the same level as a year earlier, at least according to the Taiwanese MND. In 2019, the numbers of each type of Taiwan's armed forces remained at the same level (The Military Balance, 2020). In 2020, according to the calculations of the Globalfirepower website, the Taiwanese army is expected to amount to 165.000 soldiers, while the state of the Chinese army will be about 2.183.000 without reserves (Globalfirepower, 2020).

Despite the modern equipment of the Taiwanese army, the threat that the military of this country is talking about, may be the lack of an adequate number of trained recruits to operate it in the future. The professionalization of the army contributed to the decline in the size of the army, but also to the reduction of the time of service in the army. In Taiwan, conscripts spend 12 or 4 months in the army, depending on their age. Neither in either case it is possible to train a fully professional soldier. In addition to the abovementioned conscripts, the socalled "Professionals" whose service time is 4 years. All of this is worrying Taipei staffers about the future.

According to the latest complete data for 2019, Taiwan's land forces + following commands: 3 corps HQ and 5 defense commands HQ; forces manoeuvre: 4 - armored brigades, 3 - mechanized infantry brigades, 6 - light infantry brigades and in reserve 21 light infantry brigades. In addition to the above-mentioned units, the army had a combat support: 3 artillery groups, 3 engineer groups, 3 CBRN (chemical, biological, radiological, nuclear, explosive) groups, and 3 signals groups. Apart from them, there were also coastal defense forces in the form of 1 anti-ship missile battalion.

Changes in Taiwanese-Chinese relations in recent years have intensified especially with the election of the presidentCaj Ing-wen in January 2016. The policy pursued by the new president has increased Beijing's political and military pressure on Taiwan. Manifestations of Chinese authoritarian behavior towards Hong Kong residents or its own citizens, as well as large expenditure on armaments in that country, led to increased Taiwanese opposition to unification with Beijing and led to military reforms. China, led by President Xi Jinping, increased its claims against the countries of the region including in particular Taiwan. The Ministry of National Defense of Taiwan (MND) said in its Quadrennial Defense Review 2017 (QDR) that there had been a marked improvement in Chinese operational capabilities in recent years, as well as the construction of advanced weapons and their conversion which, as the Ministry believes, could lead to a possible blockade of Taiwan by Chinese troops. 
Beijing also has, according to MND, the ability to quickly capture the offshore islands of Taiwan. All of this greatly complicates Taiwan's security environment. This strategic environment led to the adoption by MND of the doctrine of strong defense and multidimensional deterrence. This goal is to be served by cooperation and the purchase of weapons from the USA. Washington in June 2017 finalized the Taipei agreement, thanks to which Taiwan gained: surface-to-air Standard Missile-2 (SM-2) Block IIIA, Mk. 54 Lightweight Torpedo conversion kits, the MK48 Mod 6 Advanced Technology Heavyweight Torpedo, the AGM-154C JSOW (Joint Standoff Weapon) air-to-ground missile and upgrades the AGM-88B HARM (High-Speed Anti-Radiation Missile). Taiwan is also developing, independently or in cooperation with the US, automated coastal defense systems (the "Tan An" Coastal Defense Rocket System and the XTR-102 System) (The Military Balance, 2018).

Due to the geostrategic threat, the challenge for Taiwan has become to forge strong ties with Japan, which also has territorial disputes with the PRC and fears that Beijing will gain too much advantage in the Pacific. However, they did not bring large official results.

The Ministry of Defense of Taiwan started stronger efforts from 2016 to recruit specialists in defense matters so far related to the civil sectors. In 2017, the cost of maintaining military personnel accounted for $46 \%$ of the total defense budget, military investments (including purchases) accounted for approximately $30 \%$, and the remainder for over $20 \%$ was spent on operating, maintaining and maintaining military equipment. The administration of the new president has also made efforts to develop indigenous arms manufacturers, especially for the land forces. One speaks about the Ordinance Readiness Development Center (ORDC), which produces various armored vehicles; and the semiprivate NCSIST, which produces missiles, UAVs and other platforms. ORDC manufactures primarily the CM-32 Yunpao armored vehicle, the CM-21 armoured personnel carrier (an indigenous design based on the US M113 armored personnel carrier) and self-propelled howitzers. Of great importance in the defense industry of Taiwan is primarily the Taoyuanbased NCSIST, which produces the Tien Kung (I, II and III) air-defense system, the Tien Chien (I, II) air-to-air missile, the Antelope air defence system, Hsiung Feng (I, II and III) anti-ship cruise missiles, the Hsiung Feng IIE landattack cruise missile, the Wan Chien stand-off airto-ground cruise missile, the Ray-Ting 2000 artillery multiple-launch rocket system, UAVs and various automated coastal-defense systems.

In 2018, the US administration of Donald Trump supported Taiwan's defense efforts, which also involved the sale of modern equipment. In September, another agreement decided that Taipei would purchase spare parts for the aviation industry and obtain logistical support from Washington. Demographic pressure in 2017 and 2018 influenced the introduction of plans to reduce the armed forces and the reduction of conscription.

The deepened modernization and expansion of China's armed forces accelerated the efforts of the USA, Japan and Taiwan in 2019 to find ways to greater military balance in the Taiwan Strait, which meant a reduction in Chinese advantage in this region (Werner, 2019). This year, the USA strengthened its presence in the Far East by carrying out nine patrols in the Taiwan Strait (Mierzejewski, Chatys, Ciborek, 2020). The most recent report by the Taiwan Ministry of Defense: National Defense Report, issued in September 2019, which is published every two years, stressed Taiwan's support for the US Indo-Pacific Strategy, which also highlighted cooperation with the US allies in the region, especially in 
the areas of security and new technologies (National Defense Report, 2019). The report also details the agreed US arms sales: including M1A2T Abrams main battle tanks ${ }^{4}$ (Surdacki, 2020), BGM-71 TOW $^{5}$ and FGM-148 Javelin anti-tank missiles, and FIM-92 Stinger surface-to-air missiles. The acquisition of the M1A2T Abrams in particular will greatly increase the strength of the ground forces of the Republic of China, initiating the introduction of a new generation of tanks to the army. The Abrams (Reuters, 2019) will replace the long-serving tanks of the M48/M60 family, which until now were the main type of equipment in Taiwan's armored component. From a strategic point of view, it was very important to conclude a contract of sale of August 2019 between Taiwan and the USA for the sale of $66 \mathrm{~F} 16 \mathrm{C} / \mathrm{D}$ Block 70 combat aircraft. These orders strengthened Taiwan's position vis-à-vis China, having a deterrent effect, but also confirmed Taipei's good relationship and alliance with Washington.

The efforts of the ROC to introduce into service CM-34 wheeled infantry fighting vehicles from the Yunpao family (Cloud Leopard) were a great success. The first order for 32 copies was delivered by the end of 2019. In August 2020, 21 more vehicles were ordered for the Taiwanese gendarmerie. Overall, it is planned to produce 284 CM-34 (Chen Chun-hua, Ko Lin, 2020).

As far as artillery is concerned, the armed forces of the Republic of China applied for the purchase of M109A6 Paladin self-propelled howitzers from the United States. The number of planned orders is undisclosed, but the media estimates this number at around 100 M109A6 artillery pieces. As of 2019, the current ROC Army artillery consists of fairly outdated M109A2 and M109A5 systems, 8-inch M110A2 self-propelled howitzers and towed $155 \mathrm{~mm}$ M114 howitzers.

As in previous years, relations with the PRC and the maintenance of the development of military potential dominated Taipei's security policy. There were also further efforts to make the army fully professional based on volunteers rather than recruit recruits, largely influenced by demographic pressure. Due to the lack of potential suppliers of equipment from abroad, Taiwan is modernizing its current industrial centers and developing defense

\footnotetext{
4 As Surdacki R. writes, "According to the agreement of July 2019, Taiwan will acquire two Abrams tank battalions. As part of the package, in 2023-2026, the Taiwanese armed forces will receive a total of 108 M1A2T Abrams MBTs, 14 M88A2 Hercules technical support vehicles and 16 M1070A1 HET heavy technology transporters. In addition, the ordered package includes full armament (including $7.62 \mathrm{~mm}$ universal machine guns or $12.7 \mathrm{~mm}$ large-caliber machine guns), ammunition (various types) and spare parts and auxiliary equipment. The agreement also covers the armor technology in export version, AGT-1500 tank engines, X-110 tank gears, as well as »Hunter-Killer « system technology, including remotely controlled weapons modules CROWS-LP and the independent commander's thermal imager (CITV) and other parts spare parts and auxiliary equipment". See more broadly (Surdacki, 2020).

5 In 2018, Taiwan bought a batch of 460 TOW 2B Aero missiles for over \$ 130 million from Raytheon in the US. Further purchase negotiations were also conducted for 2019, which were to include the delivery of missiles and launchers of the aforementioned TOW 2B Aero for approximately USD 375.3 million. The deliveries are planned until 2028. In total, approximately 1240-1700 TOW 2B missiles, 57 launchers and vehicles are to be delivered. See more broadly, Taiwan is building an anti-tank shield, Defense 24 (2020), https://www.defence24.pl/tajwan-buduje-paniempancerna-tarcze.
} 
production there. In 2019, the government initiated a new defense and industrial policy to further strengthen the independent production of military equipment ${ }^{6}$.

\section{CONCLUSIONS}

The ROC, wishing to maintain independence and scare away its main potential aggressor, i.e. the PRC, must constantly modernize and expand its armed forces, including the land army. The PRC has enormous population, economic and military advantages over Taiwan, and has also accelerated the modernization of its armed forces, but despite this, Taiwan tries to reduce it in the geopolitical game in East and South Asia. Taipei owns and develops modern armed forces, both land and others, producing them locally (the Hsiung Feng III missile) or, more often, importing them from the USA. One means in particular the M1A2T Abrams or BGM-71 TOW tanks. Limiting the number of soldiers in the Taiwanese army for the sake of even greater professionalism and specialization does not necessarily mean a deterioration in the quality of training or combat capability. On the contrary, a professional army with modern equipment in today's world is able to ensure the security of each country in a more coordinated way. Another advantage of Taiwan is having a developed economy and information technology so important in the design of modern weapons. Taipei is also increasing its military budget as seen in the announcements for 2021 (Reuters, 2020). Taiwan's independence is not possible without having allies. The main such country for Taipei is the United States, and then countries that feel threatened by mainland China or share similar democratic and political values, i.e. Japan, South Korea and India.

The issue that Taiwan must pay attention to is the growing importance of the PRC in the last decade. Beijing feels stronger in the Pacific due to the economic crisis in the US of 2008 and the following years. However, currently China has lost much of its support worldwide as a result of the Covid-19 pandemic, which makes it less involved in international conflicts in the Pacific, especially when it comes to the use of hard force. More and more likely is the so-called the American pivot to the Pacific (Bartosiak, 2016), which is feared by China. As a result of this and the detonators occurring in this region, a conflict may arise over a new balance of power between the US and the PRC (Allison, 2018). Taiwan's declaration of independence in the wake of US support could also lead to war. In particular, the US is afraid of the PRC's exit to the open Pacific, should Taiwan be unified or conquered. Geopolitical contradictions, i.e. misunderstandings between interests or traditional spheres of influence, may exacerbate tensions between Taiwan and the US and the PRC.

The process of modernization of the Taiwanese army in 2017-2020 was stable, accelerating in some periods. Taiwan's defense budget expenditure throughout the analyzed period was at a similar level, but increased despite the epidemiological crisis in 2020 and with the growth in the potential threat from the PRC. Despite having modern components in the army, some of them are already obsolete (artillery), which strengthens Beijing's advantage in the event of an invasion of Taiwan.

As a result of the military reforms undertaken and the continuous modernization of, inter alia, land forces, Taiwan may become a very strong fortress to be conquered if Beijing

\footnotetext{
${ }^{6}$ The Taiwanese have high hopes for the Hsiung Feng III supersonic missile being implemented for
} domestic production, which is guided by radar and has a range of 1.5 to even 2 thousand. km. 
decided to do so. Especially today, when China's economy and reputation have been severely undermined by Covid-19 pandemic. In addition, Taipei's position is strengthened by the alliance with the US, which may offer not only the transfer of modern technologies, but also political support following the armaments contracts.

\section{REFERENCES}

Allison, G. (2018). Skazani na wojnę? Czy Ameryka i Chiny unikna putapki Tukidydesa? Bielsko-Biała.

Bartkiewicz, A. (2020). Tajwan zwiększa wydatki na obronność o ponad 10 proc. [Access: 24.09.2020]. Access on the internet: https://www.rp.pl/Chiny/200819793-Tajwan-Zwiekszawydatki-na-obronnosc-o-ponad-10-proc.html.

Bartosiak, J. (2016). Pacyfik i Eurazja. O wojnie. Warszawa.

Bush, R. (2015). .At cross purposes: US-Taiwan relations since 1942. Routledge.

Chen Chun-hua, Ko Lin (2020). Military police to get CM-34 armored vehicles [Access: 30.09.2020]. Access on the internet: https://focustaiwan.tw/politics/202008250020.

Ching-Tse, Ch. (2020). Taiwan ranks 26th in global military strength index [Access: 24.09.2020]. Access on the internet: https://www.taiwannews.com.tw/en/news/3945511.

Globalfirepower (2020). [Access: 27.09.2020]. Access on the internet: https://www. globalfirepower.com/country-military-strength-detail.asp?country_id=taiwan.

Góralczyk, B. (2019). Powrót Chin do centrum światowej sceny. „Rocznik Strategiczny”, Vol. 24, 2018/19. Warszawa.

Mierzejewski, D., Chatys, M., Ciborek, P. (2020). Globalny i regionalny wymiar polityki zagranicznej Chińskiej Republiki Ludowej. „Rocznik Strategiczny”, Vol. 25, 2019/20. Warszawa.

Mitchell, B.R. (2003). International historical statistics: Africa, Asia \& Oceania, 1750-2000.

National Defense Report (2019). [Access: 1.10.2020]. Access on the internet: https://www.ustaiwandefense.com/tdnswp/wp-content/uploads/2020/02/Taiwan-NationalDefense-Report-2019.pdf.

Reuters (2019). [Access: 4.10.2020]. Access on the internet: U.S. State Department approves possible $\$ 2.2$ billion arms sale to Taiwan. https://www.reuters.com/article/us-usa-taiwan/u-sstate-department-approves-possible-2-2-billion-arms-sale-to-taiwan-idUSKCN1U32HT.

Reuters (2020). Taiwan proposes 10\% increase in defense spending for 2021 [Access: 5.10.2020]. Access on the internet: https://www.taiwannews.com.tw/en/news/3986450.

SIPRI Military Expenditure Database (2020) [Access: 27.09.2020]. Access on the internet: https://sipri.org/databases/milex.

Sułek, M. (2013). Potęga państw: modele i zastosowania. Warszawa.

Sułek, M., Białoskurski, R., Kiczma, Ł. (2019). Potęga państw. Rankingi potęgometryczne [Access: 1.10.2020]. Access on the internet: http://prnet.org.pl/img/pub/pot\%C4\%99gapa\%C5\%84stw-2019-rankingi-pot\%C4\%99gometryczne.pdf.

Sułek, M., Kiczma, Ł. (2020). Potęga państw. Rankingi potęgometryczne. Warszawa.

Surdacki, R.(2020). Tajwan przygotowuje się do przyjęcia Abramsów (2020) [Access: 30.09.2020]. Access on the internet: https://www.defence24.pl/tajwan-przygotowuje-sie-doprzyjecia-abramsow. 
Szopa, M. (2020). Defence 24. Rekordowy wzrost wydatków na zbrojenia. To już koniec? [Access: 27.09.2020]. Access on the internet: https://www.defence24.pl/rekordowy-wzrostwydatkow-na-zbrojenia-to-juz-koniec-komentarz.

Szopa, M. (2020). Defence 24. Tajwan: armii brakuje rezerw. Powodem „rofesjonalizacja” [Access: 28.09.2020]. Access on the internet: https://www.defence24.pl/tajwan-armii-brakujerezerw-powod-profesjonalizacja-komentarz.

Taiwan Demographics (2020). [Access: 27.09.2020]. Access on the internet: https://www. worldometers.info/demographics/taiwan-demographics/\#pop.

Tajwan buduje przeciwpancerna tarcze. Defence 24 (2020) [Access: 30.09.2020]. Access on the internet: https://www.defence24.p1/tajwan-buduje-przeciwpancerna-tarcze.

The Military Balance 2017. International Institute for Strategic Studies-Routledge. London 2017.

The Military Balance 2018. International Institute for Strategic Studies-Routledge. London 2018.

The Military Balance 2019. International Institute for Strategic Studies-Routledge. London 2019.

The Military Balance 2020. International Institute for Strategic Studies-Routledge. London 2020.

The Republic of China Yearbook (2014). Executive Yuan, R.O.C.

Werner, B. (2019). China's Newest Aircraft Carrier Transits Taiwan Strait [Access: 5.10.2020]. Access on the internet: https://news.usni.org/2019/12/26/chinas-newest-aircraft-carrier-transitstaiwan-strait.

Ye Zicheng (2011). Inside China's Grnad Strategy. The Perspective from The People's Republic. Lexington.

DOI: $10.7862 /$ rz.2020.hss.50

The text was submitted to the editorial office: October 2020.

The text was accepted for publication: December 2020. 